\title{
An Organizational Objective To Incorporate Social Responsibility
}

\author{
Joseph W. Kennedy, (Email: jwk21@ cox.net), Edward Waters College
}

\begin{abstract}
Organizational leaders are continuously making decisions and plans that will affect the long-term value of their firms. Organizational strategic plans without corporate social responsible determinants, such as Enron's and MCI Worldcom's accounting policies, affected thousands of employees, stakeholders, and the firm's overall reputation throughout the world. I proclaim that corporate social responsibility enhances organizations' overall competitive strength in their markets. Thus, a firm who adopts, teaches and creates ethical business practices within the organization's internal environment and promotes those strategies in their remote environment, through their value chains, will create profitable long-term value for the organization. Michael Porter's work of the 1980's, "Competitive Strategies," is a method that should be utilized to enhance ethical practices for an organization, through strategic development; however, a research question has emerged:
\end{abstract}

\section{DOES CORPORATE SOCIAL RESPONSIBILITY ENHANCE ORGANIZATIONS MARKET STRENGTH?}

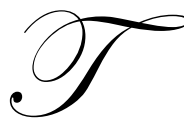

his research is to provide an organizational view to strategically implement corporate socially responsible processes into an organizations strategic plan. The research question to be answered: Does an organization need to be socially responsible in order to meet long-term strategies? The issues of corporate social responsible strategic planning determinants will involve Michael Porter's works of the Competitive Advantage and (1985) the Competition in Global Industry (1986).

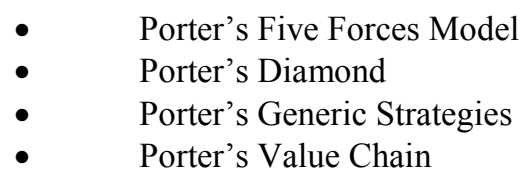

A historical account of testing individuals based on Kohlberg's four psychological components, is determined through moral behavior and development of people according to Rest \& Narvaez (1994) "Moral Development in the Professions." The key factors of ethical development by Kohlberg (1981) conducted research to determine how people behaved ethically, according to their specific maturity levels. According to Rest and Narvaez (1994), testing people at various levels of maturity will determine specific identifiers of their ethical values. Thus, Rest and Narvaez developed the Defining Issues Test (DIT), to measure the moral morality of people in the professions.

\section{LITERATURE REVIEW}

In order for businesses to compete in a global economy, organizations must facilitate ethical practices in their organizational processes. According to DiMaggio \& Powell, "Corporations are subject to multiple pressures to operate in a socially responsible fashion. Some of these influences are external to a company, such as explicit government requirements or more general expectations of social legitimacy" (1983; Wood, 1991, p. 147-160). Andrews (1971, p. 120), defined Corporate Social Responsibility (CSR) as an intelligent decision-making process by individuals and corporations, with the objective of providing all societies with restraints on destructive activities, even though these activities can achieve profitable and potential market gains. When businesses pursue unethical activities, 
to receive high profits, individual bonuses, or enormous market share gains. Tedlow states, "If ethical behavior always paid, everyone would always be ethical" (Jones, 2002, p. B 08). According to Tedlow (Jones, 2002, p. B.08), the ethics of a business does not show up on a company's balance sheet. However, according to the article by Jones (2002, p. B 08), a company such as Johnson and Johnson who have core values, which are supported by top management, ensure that any possible negative socially responsible action ceases, for example, the case of the Tylenol medicine, which was tainted with cyanide. Top managers of Johnson and Johnson immediately removed all Tylenol products from their shelves to prevent any future loss of life, even though the firm initially lost millions of dollars. The most prolific aspect for Johnson and Johnson during this situation was to protect their long-term value of the firm.

Table 1: Kohlberg's Four Psychological Components Of Determining Moral Behavior

Component I: Moral Sensitivity. (Interpreting the situation)

The awareness of how our actions affect other people. It involves being aware of different possible lines of action and how each line of action could affect the parties concerned.

Component II: Moral Judgement. (Judging which action is morally right/wrong)

The line of actions - the determinants of the DIT judges the actions of the respondent's based on what is morally right or wrong.

Component III: Moral Motivation. (Prioritizing moral values relative to other values)

The results are tabulated, based on a respondent's motivation to sufficiently place their values higher than the prescribed moral values.

Component IV: Moral Character. (Having courage, persisting, overcoming distractions, implementing skills)

Involves the ego strength, perseverance, backbone, strength of conviction, and courage. Psychological toughness and strong character are a necessary factor for this component.

From: Rest, J. R., \& Narvaez, D. (1994); Moral development in the professions: Psychology and Applied Ethics, Hillsdale, NJ: Lawrence Erlbaum Associates. p. 23.

\section{STRATEGIC PLANNING}

According to Waddock, Bodwell and Graves (2002, p. 132 - 148), businesses today are confronted by numerous stakeholder groups that require Total Responsibility Management (TRM) by the organization to comply with value added products and services for all societies, and to provide safe environmental practices. The basis of the authors TRM approach is founded on the organizations vision and mission statements of the firm. The vision statement provides a serious organizational commitment to their socially responsible actions. Thus, the values of the top executives in a firm provide a blue print for the core values, which are implied in the corporate strategy. The mission of the firm is commensurate of the core values and vision, which is directed towards the entire organization and its key partners. The authors identify that the key element for TRM is to develop integrity within the internal environment of the organization, and to exhume or provide integrity to the external environment. 
FIGURE 1: The Development Of Total Responsibility Management (TRM)

From "Responsibility: The new business imperative," by S. A. Waddock, C. Bodwell, and S.B. Graves, 2002, AOM Executive, 16, (2), p. 134

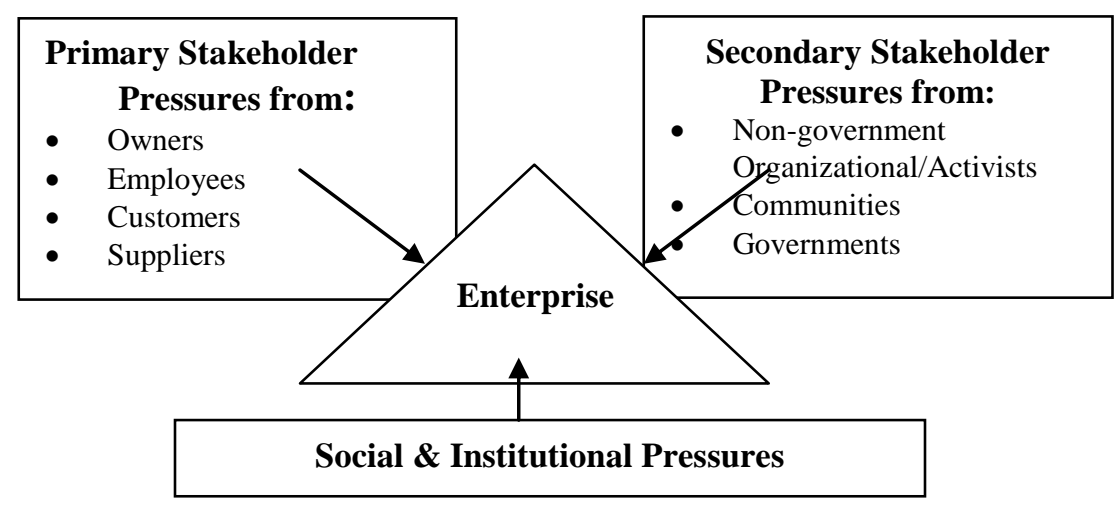

FIGURE 2: Total Responsibility Management (TRM)

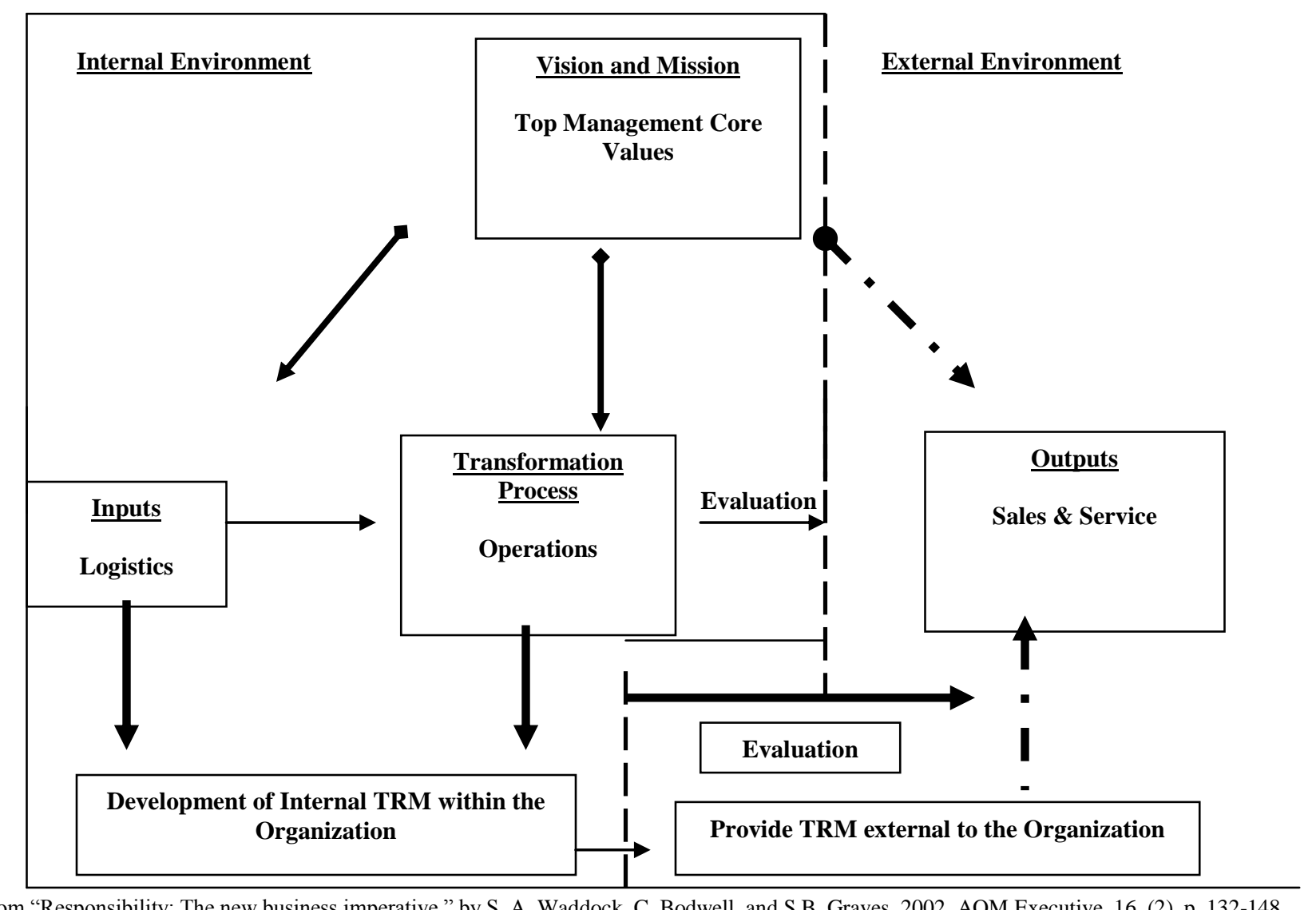

From "Responsibility: The new business imperative," by S. A. Waddock, C. Bodwell, and S.B. Graves, 2002, AOM Executive, 16, (2), p. 132-148. 
Johnson and Greening (1999, p. 564 - 576) conducted research on a new form of a stakeholder group known as "Institutional Investors." This new stakeholder group seeks high financial performance; however, they have a strong interest in a firm's strategies, organizational activities (value-added activities) and other stakeholders internal or external to the firm. The Institutional Investors seek long-term results, which provide them return on their investments (ROI), as well as a socially responsible organization, which creates value throughout their market. The results of the study by Johnson and Greening $(1999$, p. 564 - 576) identified that there are several different types of Institutional Investors, which have different goals for the firm in which they invest. Within the same article, Smith (1996, p. 227 - 252) provided evidence that different stakeholder groups can change corporate governance structures and policies to facilitate higher returns on investments (ROI) for the organizations shareholders.

\section{CORPORATE SOCIAL RESPONSIBILITY}

The specific strategy of any organization must be based on creating value for all stakeholders (ethical decision-making). According to Pohlman and Gardiner (2000, p. 3-5), Value Driven Management (VDM) is designed to effectively accelerate the pace of change. The value theory identifies motivators, in what people value, driving their behaviors. In the context of strategy, Pohlman and Gardiner identify Value Over Time (VOT) for organizations as a measuring mechanism to ensure that the organization is sustaining long-term value for the organization, such as the case for Johnson and Johnson, when confronted with a decision to remove all of their products from their shelves from various partners. The top executives of Johnson and Johnson believed in their corporate credo and protected the long-term value of their firm. According to Argyres and McGahan's interview of Michael Porter (2002, p. 41-52), Porter discussed the topics of anti-trust policies, accounting policies, education reform, environmental protection and urban revitalization. These areas are of a concern for corporate socially responsible organizations, in which they must act accordingly to meet specific stakeholder needs. Michael Porter stated that the five forces model is "time invariant," which could be adapted at any point in time, to a changing environment.

\section{FIGURE 3: Porter's Competitive Strategy Five Competitive Forces}

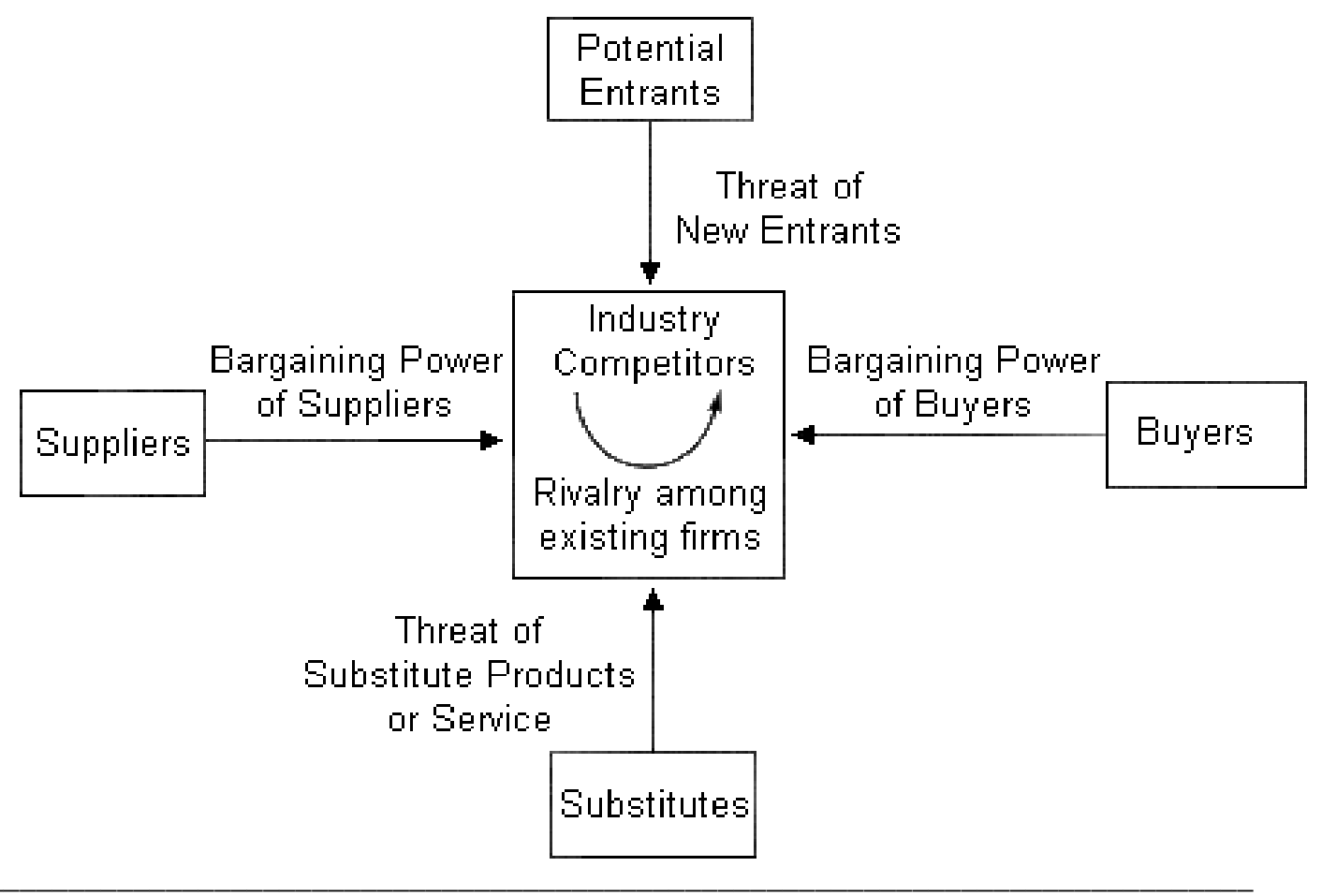

From ” The Competitive Advantage,” by M. E. Porter, 1985, New York: The Free Press, p. 5. 
The purpose of Porter's model is to gain a thorough understanding of a particular industry by analyzing the external environment; thus the analysis of the Five Forces Model identifies competitive advantages. From this analysis, a determination can be made of both the competitive situation and profit potential of a particular industry (Porter, 1980).

- $\quad$ Porter's first element is the threat of new entrants into the markets. This could be due to a variety of reasons that include a need for capital, a need for brand awareness, a need for economies of scale or the result of government regulations. For example, Ford Motor Company sought a new partnership in 2001 to replace Firestone.

- $\quad$ Porter's second element of the model is the power of suppliers. In any industry suppliers exert significant influence through the availability of raw materials and the subsequent impact on costs. For example, Firestone lost their ninety-six year old partnership with Ford Motor Company, due to the failure of their automobile tires.

- $\quad$ Porter's third element is the power of buyers. This represents the extent of bargaining that the buyers of the product can exert in regards to the industry or business. Since the consumers of the service pay such a small portion of the charges they are less concerned about price and are more focused upon the overall quality of the product or service. For example, consumers diverted their purchases of Nike products, due to the allegations of child abuse in Nike's overseas manufacturing plants. According to Kolk \& Tulder's article in 2002 (p. 291-301), multinational firms have taken a stance by setting a standard for corporate conduct for child labor issues and approving children's working conditions, education and health issues.

- $\quad$ Porter's fourth element is the availability of substitute products. The availability and pricing of substitute products can have a significant impact on a business strategy. The services offered by businesses are unique in that there are also few if any substitutes for these services of this nature. For example, consumers are purchasing less of McDonald's products, due to unsatisfactory customer service.

- $\quad$ Porter's fifth and final element is the industry rivalry. The number of competitors, degree of product differentiation, cost conditions and overall competitive diversity can have substantial impact on strategies to be adopted. (Porter, 1980) For example, in the fast food market, there is intense rivalry in the industry.

When determining the national competitive advantage of a firm based on the organizations overall worth, it is determined according to Michael Porter's Diamond of national competitive advantage. The four key areas must be identified to determine the nations competitive advantages.

1. Organization strategy, structure and rivalry.

2. Demand conditions.

3. Related and supporting industries.

4. Factor conditions. 
FIGURE 4: Porter's Diamond Of National Competitive Advantage

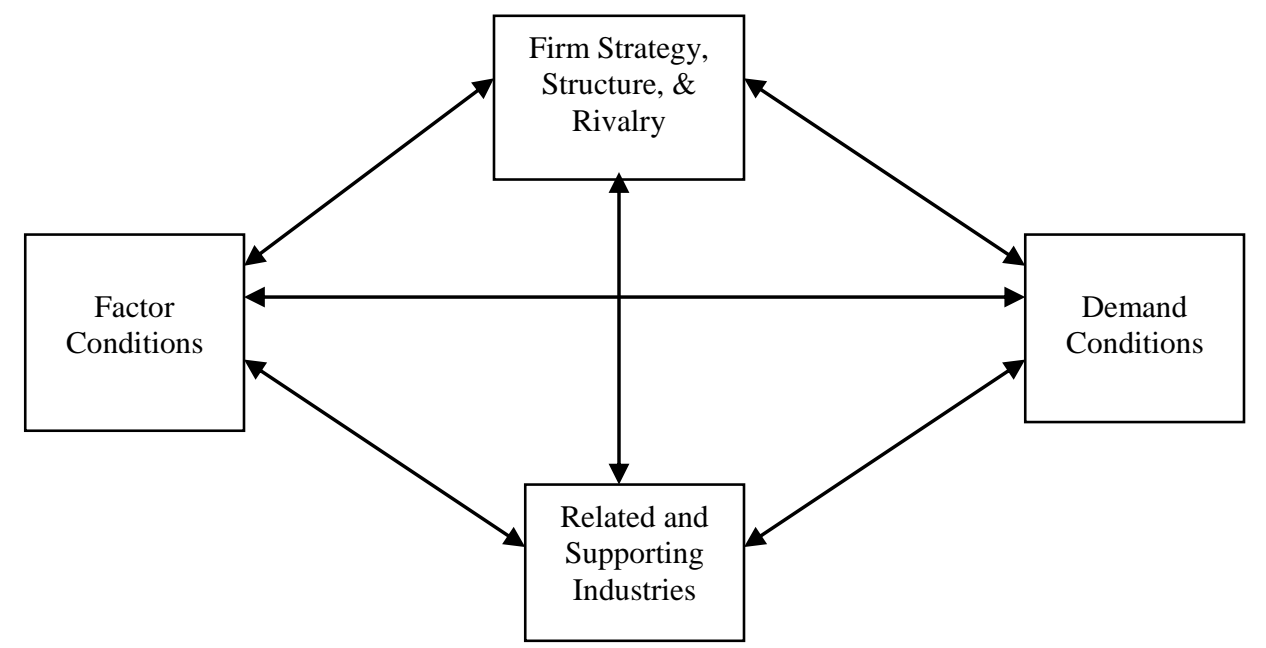

From " The Competitive Advantage of Nations," by M. E. Porter, 1990, New York: The Free Press.

\section{However, Porter States There Are Unethical Practices By Top Corporate Executives:}

Too many executives are focused on raising the stock prices of their companies in destructive ways for economic value. There are fundamental public policy issues about the system we have created, over the last five years. A second fundamental public policy issue for the U.S. is inequality, and particularly economically distressed citizens and communities. There have been decades of policy failure because we've tried to address inequality as a social problem, rather than as an economic problem, the lack of opportunity to participate in the market system. (Argyres \& McGahan, 2002, p. 50).

Porter identified the factor conditions as a determination of trade; however, the ability of a specific nation to create, upgrade and improve innovative factors is the essence of the factor conditions. International or multinational organizations seek nations that can provide their organizations with skilled laborers (Porter, 1990, p. 73-74), however, according to an article by Asgary and Mitschow (2002, p. 239-246), most companies have basic policies concerning employee integrity, sexual harassment, and confidentiality; yet, many firms have not established policies concerning bribery, child labor issues and human rights violations abroad (Drake, 1998, p. 9-12). These two authors state that there is a need for global business ethics; but, the complexities of the issues make it very difficult to set a universal code of ethics. One of the compounding problems multinational firms face, is diminishing contact with the culture of their home country. Porter identified the characteristics of the market, which reflects the competitiveness of the firm, thus, the assertiveness of customers provides healthy demand conditions (Porter, 1990, p. 73-74). The infrastructure of a nation's industrial base according to Porter is known as "Related and Supporting Industries." The strength and the partnerships of a variety of different industries denotes specific advantages of firms working together, thus, this creates a harmony within the nation to be competitive (Porter, 1990, p. 73-74). An organizational strategy and structure determines a firm's competitive rivalries. According to Porter, different organizations seek different strategies to meet their vision or long-term goals for the firm (Porter, 1990, p. 73-74).

Michael Porter's (1990, p. 11-16) Generic Strategies are a process, in which organizations attempt to achieve their strategic goals through a core idea, derived from the top executives of the firm. Porter's Generic Strategies:

1. Cost leadership: An organization seeks to be the low cost leader in the market.

2. Differentiation: An organization seeks leadership by obtaining consumer loyalty in their products and services, even if the product costs are higher, due to the perception of the product or service delivered by the firm. 
3. Focus/niche: A firm can attempt to grow within a market by focusing on specific niches in the market, by developing either a cost focused strategy or focused differentiation strategy (1990, p. 11-16).

All private and for profit organizations seek to enhance stockholder worth, which is the essence of forming a generic strategy for an organization. However, Porter identifies that the generic strategies are sustainable, meaning value creating. In order for a product or service to be value creating, the specific generic strategy of a firm must enhance stakeholder value, not just stockholder value. Porter states:

A firm can create sustainable differentiation if its price premium exceeds the extra costs incurred in being unique. A differentiator, therefore, must always seek ways of differentiating that lead to a price premium greater than the cost of differentiating. A differentiator thus aims at cost parity or proximity relative to its competitors, by reducing costs in all areas that do not affect differentiation. (1990, p. 14)

A firm's reputation of providing excellence and customer value can be enhanced throughout the value chain by providing:

- $\quad$ The ability to serve buyer needs.

- $\quad$ Ease of maintenance of products for the buyer.

- $\quad$ Central locations for the point of sale.

- $\quad$ Central locations for the Point of service.

- $\quad$ Product compatibility and standardization. (Porter, 1990, p. 123 - 124)

According to an article by Cascio (2002, p. 80-91), a responsible strategy of creating value of human talents is needed, instead of organizational downsizing which erodes the value of an organization by eliminating the jobs of their thinkers and performers. Healthy organizations are reducing costs by downsizing to boost earnings. This is not a strategy; it is focusing on the short term which can adversely affect the organization's long-term strategy. "Today, if a company misses a critical new development, for example in the digital phone industry, Internet auctions, or corporate extranets (networks that connect firms to their suppliers or customers that is the entire value chain) it may never catch up" (Cascio, 2002, p. 83).

FIGURE 5: Porter's Generic Strategies Competitive Advantage

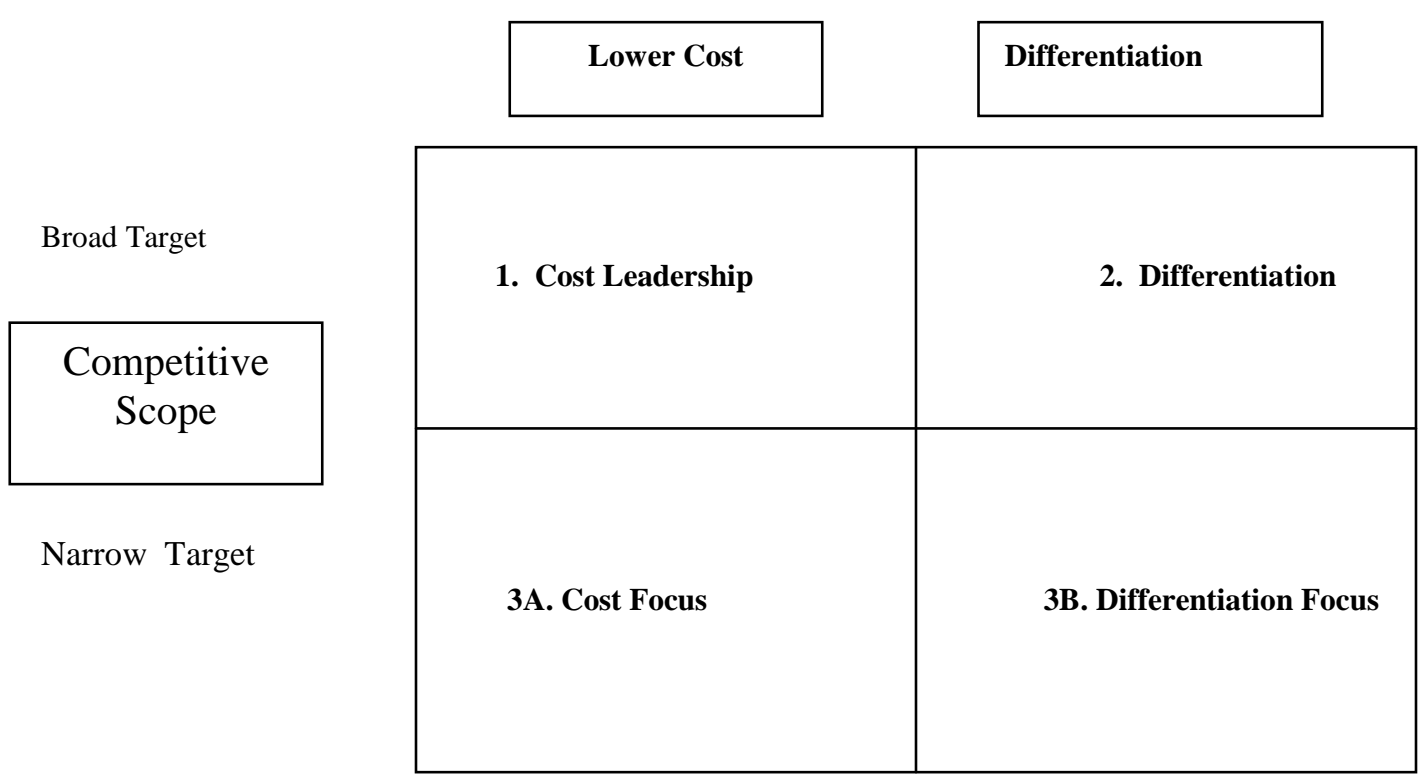




\section{STRATEGIC ADVANTAGE}

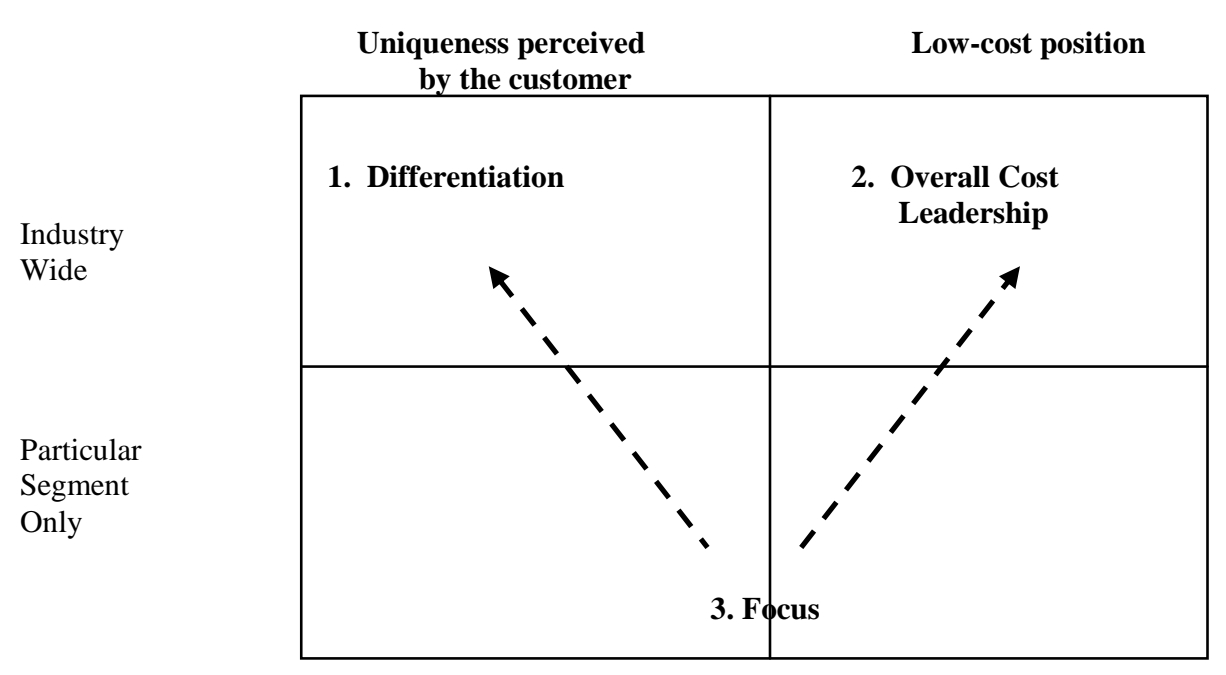

From “The Competitive Advantage," by M. E. Porter, 1985, New York: The Free Press, p. 12. " The Competitive Strategy,” by M. E. Porter, 1980, New York: The Free Press.

The value chain by Porter (1985, p. 36) identifies specific strategic activities of a firm. These activities are to enhance the overall competitive value for the organization. Different organizations have a variety of different primary and support activities. Each industry develops its core activities (primary activities) to create internal and external value for the organization. Addressing Corporate Social Responsibility (CSR) within the value chain is implied throughout the processes. The top executives of the firm must enforce socially responsible decisions and actions throughout the value chain. For example, when the Nike Corporation found out that their overseas manufacturing plant employees were abusing children, Nike Corporation's top executives should have immediately enforced child protection policies and procedures. However, like most foreign operations abroad, the top executives do not oversee the day-to-day operations and communications. Management should have been informed of the atrocities of the foreign Nike manufacturing plant, thus, Nike was responsible for not prohibiting such activities, due to U.S. government restrictions on American businesses on child labor policies. According to Kolk and Tulder (2002, p. 291301), businesses must conduct responsible operations in order to improve the situation for children abroad, such as providing subsistence, education and healthcare. Ethics training helps to legitimize and enhance organizational goals, thus, exemplifying significance of Corporate Social Responsibility (Wartick \& Cochran, 1985; Wood, 1991). The research conducted by Weaver, Trevino and Cochran, was based on information received from large U.S. companies, which supported the findings of integrated and decoupled corporate social performance on management commitments of ethical and socially responsible behavior. However, according to Paine, organizational ethical programs should place heavy emphasis on roles of management practices within the value chain of the organization (Paine, 1996, p. 477-492). 
FIGURE 6: Porter's Competitive Advantage Value Chain

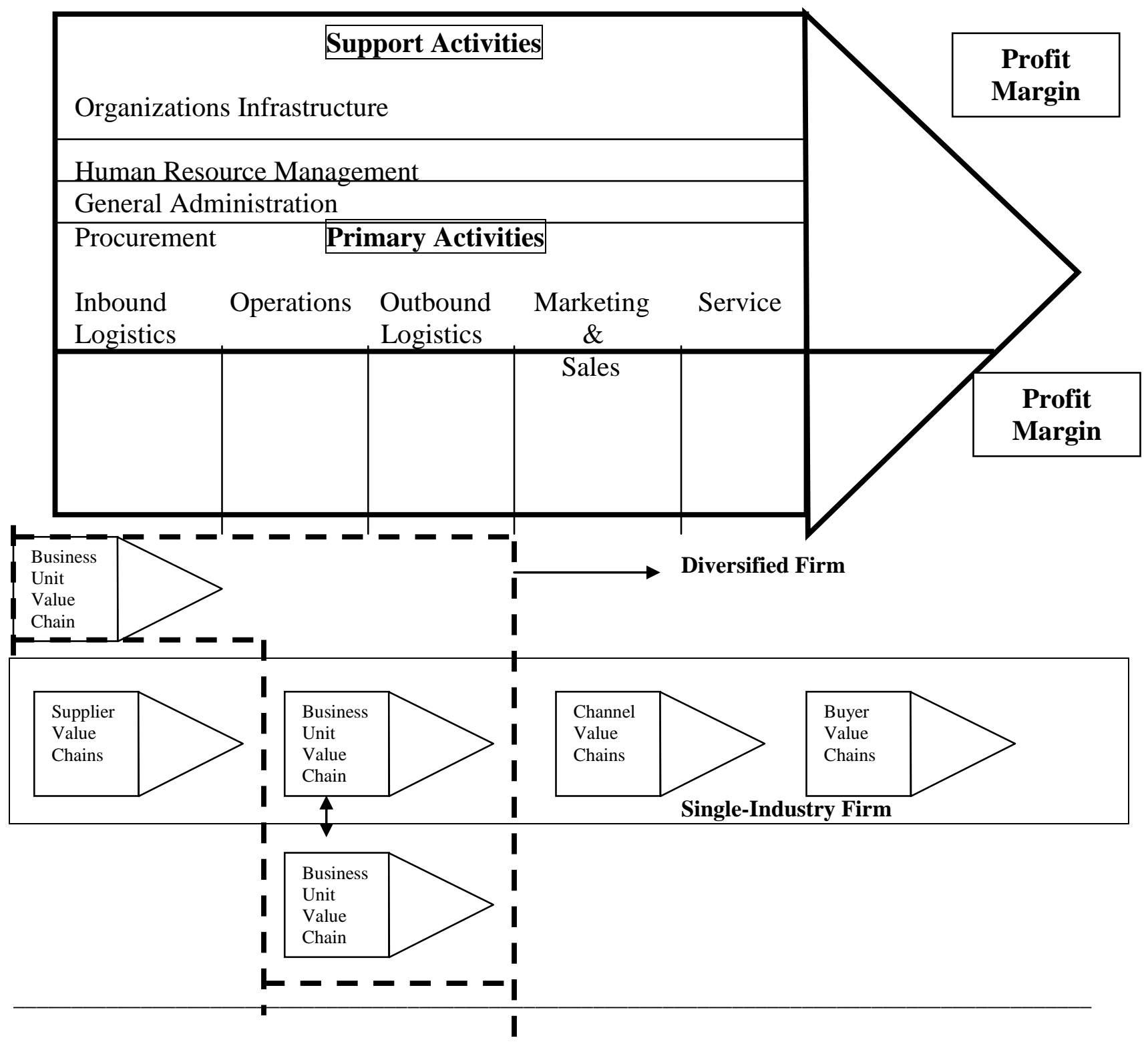

From ”The Competitive Advantage,” by M. E. Porter, 1985, New York: The Free Press, p. 35-37.

\section{CONCLUSIONS AND RECOMMENDATIONS}

Businesses throughout the world need to apply Corporate Social Responsibility factors within their organizations. In order to compete strategically in the global and domestic markets, ethics must be implied throughout the organizations internal and external environments, especially in the remote environment (economic, social, political, technological, and ecological external environment of an organization). Ethical business practices and strong adherence to international business ethics must be maintained in order for a business to compete. Businesses must apply ethical practices throughout the firm's value chain, thus according to Porter, (1985, p. 36) each facet of the value chain provides overall competitive value for the organization. 
Future research is needed to empirically test Corporate Social Responsibility based on organizational strategic planning. The test for this research must include the specific organizational strategy compared to an ethical construct, for example a product, which denotes safety applications or does not provide safety measures. The comparison of results should be applied to the firm's long-term strategy.

Corporate Social Responsibility needs to be applied across the entire organization. Organizations that seek to provide a transparent form of social responsibility within the firm to appease stakeholders will ultimately fail. Ethical practices in business evolves from the culture and climate of the organization, however the leaders of the organization must exhibit self control and restraint when it comes to personal gain. "Customers are increasingly pressuring companies to accept and manage their responsibilities through their purchasing power. Consumer pressure on corporate performance is brought to bear on corporations through consumer oriented ratings, such as J.D. Power's and Associates" (Waddock, Bodwell \& Graves, 2002, p. 132-148).

\section{REFERENCES:}

1. $\quad$ Andrews, K, R. (1971). The concept of Corporate Strategy. Burr Ridge, IL: Irwin Co. P. 120.

2. Argyres, N. \& McGahan, A. (2002). Introduction: Michael Porter's competitive strategy. Academy of Management Executive, 16, (2), 41-42.

3. Argyres, N. \& McGahan, A. (2002). An interview with Michael Porter. Academy of Management Executive, $16,(2), 43-52$.

4. Asgary, N. \& Mitschow, M.C. (2002). Toward a model for international business ethics. Journal of Business Ethics, 36, (3), 239-246.

5. Cascio, W, F. (2002). Strategies for responsible restructuring. Academy of Management Executive, 16, (3), 80-91.

6. DiMaggio, P. J. \& Powell, W. W. (1983). The iron cage revisited: Institutional isomorphism and collective rationality in organization fields. American Sociological Review, 48: 147-160.

7. Drake, M. (1998). International business ethics a dangerous sleeper: Firms may need guidance on how to handle difficult issues such as bribery and child labor. Canadian Business and Current Affairs, 57, 9-12.

8. Ford Motor Company. http://www.ford.com/mission/vision/csr

9. Jones, D. (2002). Ethics don't always pay, but lack of them always hurts; Author: Core values from top aide success. USA Today, VA: B.08

10. Johnson, R. A. \& Greening, D.W. (1999). The effects of corporate governance and institutional ownership types on corporate social performance. Academy of Management, 42, (5), 564-576.

11. Johnson \& Johnson Annual Report, Mission Statement and Code of Ethics. 1982. http://www.johnson\&johnson.com/mission/vision/csr

12. Kohlberg, L. (1981). The Philosophy of Moral Development (Vol. 1). California: Harper \& Row.

13. Kohlberg, L. (1984). The Psychology of Moral Development (Vol. 2). California: Harper \& Row.

14. Kolk, A. \& Tulder, R.V. (2002). Child labor and multinational conduct: A comparison of international business and stakeholder codes. Journal of Business Ethics, 36, (3), p. 291-301.

15. Paine, L.S. (1996). Moral thinking in management: An essential capability. Business Ethics Quarterly, 6, 477-492

16. Pohlman, R.A. \& Gardiner, G.S. (2000).Value Driven Management. New York, New York: Amacom Books.

17. Porter, M.E. (1990, March-April). The Competitive Advantage of Nations. Harvard Business Review, 73-74.

18. Porter, M. E. (1990). Competitive advantage of Nations. New York: The Free Press.

19. Porter, M. E. (1986). Competition in Global Markets. Boston: Harvard Business School.

20. Porter, M. E. (1985). The Competitive Advantage. New York: The Free Press.

21. Porter, M. E. (1980). Competitive Strategy: Techniques for Analyzing Industries and Competitors. New York: The Free Press.

22. Rest, J. R. \& Narvaez, D. (1994) Moral development in the professions: Psychology and Applied Ethics, Hillsdale, NJ: Lawrence Erlbaum Associates.

23. Smith, M.P. (1996). Shareholder activism by institutional investors: Evidence from Calpers. Journal of Finance, 51, 227-252. 
24. Waddock, S. A., Bodwell, C., \& Graves, S.B. (2002). Responsibility: The new business imperative. Academy of Management Executive, 16, (2), 132-148.

25. Wartick, S.L. \& Cochran, P.L. (1985). The evolution of the corporate social performance model. Academy of Management Review, 10, 758-769.

26. Weaver, G. R., Trevino, L. K., \& Cochran, P. L., (1999). Integrated and decoupled corporate social performance: Management commitments, external pressures, and corporate ethics practices: Academy of Management Journal: 42, (5), 539-552. 


\section{NOTES}

